\title{
Faktor-Faktor Penentu Kredit Produktif Bank Pembangunan Daerah di Indonesia
}

\author{
Erfin Effendhi ${ }^{1}$, Suyanto ${ }^{2}$ \\ ${ }^{1}$ Universitas Pancasila, Jl. Srengseng Sawah, Jagakarsa, Jakarta Selatan, 12640 \\ ${ }^{2}$ Sekolah Tinggi Ilmu Eonomi IPWI Jakarta, Jl. Letda Natsir No. 7, Cikeas Nagrek, Bogor, Jawa Barat
}

\section{INFO ARTIKEL JEL Classsification: G21 \\ E50}

Keywords: goverment capital investment, capital adequacy ratio, nonperforming loan, operational efficiency ratio and credit channeling productive.

\section{$A B S T R A C T$}

This study aimed to analyze and goverment capital investment, capital adequacy ratio, non-performing loan, and operational efficiency ratio, to credit productive at Bank Pembangunan Daerah for the period 2010 -2015. The sample used in this study were 68 banks. Methods of data analysis using multiple regression analysis model. The test is done by multiple linear regression analysis. The result of this research is the effect of government capital investment and efficiency ratio toward productive credit. However, the ratio of capital adequacy and nonperforming loans is not a determinant of the provision of productive credit in the sample under study. The results of this research have implications on the importance of research findings related to the effect of other untested financial ratios in this study, including the ratio of the amount of loans disbursed to the receipt of funds from third parties.

\begin{abstract}
A B S T R A K
Penelitian ini bertujuan untuk menganalisis pengaruh penyertaan modal, rasio kecukupan modal, kredit bermasalah dan rasio efisiensi bank terhadap kredit produktif pada bank pembangunan daerah. Sampel diuji sebanyak 68 bank selama 2010-2015. Pengujian dilakukan dengan analisis regresi linier berganda. Hasil penelitian adalah terdapat pengaruh penyertaan modal dan rasio efisiensi terhadap kredit produktif. Namun, rasio kecukupan modal dan kredit bermasalah bukan penentu pemberian kredit produktif pada sampel yang diteliti. Hasil penelitian berimplikasi pada penting temuan riset terkait pengaruh rasio keuangan lain yang belum diuji dalam penelitian ini, termasuk rasio jumlah kredit yang disalurkan dengan penerimaan dana dari pihak ketiga.
\end{abstract}

\section{Pendahuluan}

Tujuan bernegara sebagaimana diamanatkan dalam pembukaan Undang-Undang Dasar Negara Tahun 1945 (UUD 1945) adalah melindungi segenap bangsa Indonesia dan seluruh tumpah darah Indonesia, memajukan kesejahteraan umum, mencerdaskan kehidupan bangsa, dan melaksanakan ketertiban dunia yang berdasarkan kemerdekaan, perdamaian abadi dan keadilan sosial. Dalam rangka pencapaian tujuan bernegara inilah, negara menyelenggarakan fungsi pemerintahan dalam berbagai bidang, sehingga timbul konsekuensinya pada hak dan kewajiban bagi negara, konsekuensi ini termasuk bidang keuangan negara. Asshiddiqie (2010) juga menjelaskan ada tiga tujuan negara, yaitu (1) untuk memelihara ketertiban dan ketenteraman, (2) mempertahankan kekuasaan, dan (3) mengurus hal-hal yang berkenaan dengan kepentingan-kepentingan umum.

Undang-Undang (UU) No. 17 Tahun 2003 tentang Keuangan Negara, khususnya pasal 1 ayat 1 dinyatakan bahwa pengertian Keuangan

*Email Korespondensi: ${ }^{2}$ piping.erfin@gmail.com, ${ }^{2}$ suyanto@cbn.net.id 
Negara adalah semua hak dan kewajiban negara yang dapat dinilai dengan uang, serta segala sesuatu baik berupa uang maupun berupa barang yang dapat dijadikan milik negara berhubung dengan pelaksanaan hak dan kewajiban tersebut.

Pemerintah dalam melaksanakan kewajiban keuangan negara melakukan salah satu fungsinya yaitu pengeluaran pemerintah. Pengeluaran pemerintah adalah konsumsi barang dan jasa yang dilakukan pemerintah serta pembiayaan yang dilakukan pemerintah untuk keperluan administrasi pemerintahan dan kegiatan-kegiatan pembangunan (I Gusti Ayu Putri Wahyuni, Made Sukarsa, dan Nyoman Yuliarmi, 2014).

Pemerintah juga melaksanakan kewajiban keuangan negara dalam mengelola dan mengadministrasikan pendapatan daerah. Pendapatan daerah adalah hak pemerintah daerah yang diakui sebagai penambah nilai kekayaan bersih, sedangkan Pendapatan Asli Daerah (PAD) merupakan pendapatan daerah yang bersumber dari pelaksanaan hak dan kewajiban pemerintah daerah. PAD dapat bersumber dari pemanfaatan potensi atau sumber daya daerah, baik yang dimiliki oleh pemerintah daerah maupun yang terdapat di wilayah daerah bersangkutan, pemungutannya merupakan tanggung jawab pemerintah daerah. PAD bertujuan untuk memberikan keleluasaan kepada daerah dalam menggali pendanaan dalam pelaksanaan otonomi daerah sebagai perwujudan asas desentralisasi, komponen PAD terdiri dari:
(1) pajak daerah, (2) retribusi daerah, (3) hasil pengelolaan kekayaan daerah yang dipisahkan dan (4) lain-lain PAD yang sah.

Kekayaan daerah adalah kekayaan daerah yang dikelola sendiri atau oleh pihak lain berupa uang, surat berharga, piutang, barang, serta hak-hak lain yang dapat dinilai dengan uang termasuk kekayaan yang dipisahkan pada perusahaan daerah (H. Abd. Rachim, 2015). Kekayaan daerah yang dipisahkan adalah bagian dari aset pemerintah daerah yang digunakan sebagai penyertaan modal pemerintah daerah pada perusahaan atau badan usaha, baik badan usaha milik negara/daerah (BUMN/BUMD) maupun badan usaha milik swasta atau kelompok usaha masyarakat. Hasil pengelolaan kekayaan daerah yang dipisahkan berupa bagian laba yang dibagikan (deviden) dari perusahaan atau badan usaha yang bersangkutan, dapat dikategorikan sebagai berikut (1) bagian laba atas penyertaan modal pada perusahaan milik daerah/BUMD, (2) bagian laba atas penyertaan modal pada perusahaan milik Pemerintah/BUMN dan (3) bagian laba atas penyertaan modal pada perusahaan milik swasta atau kelompok usaha masyarakat.

Permendagri No 1 Tahun 1998 tentang Bentuk Hukum Bank Pembangunan Daerah, dalam pasal 10 dinyatakan bahwa laba bersih yang menjadi bagian Pemerintah Daerah seluruhnya disetor ke Kas Daerah. Rentang waktu tahun 2010 s.d 2014 menunjukan laju pertumbuhan laba sebagai berikut:

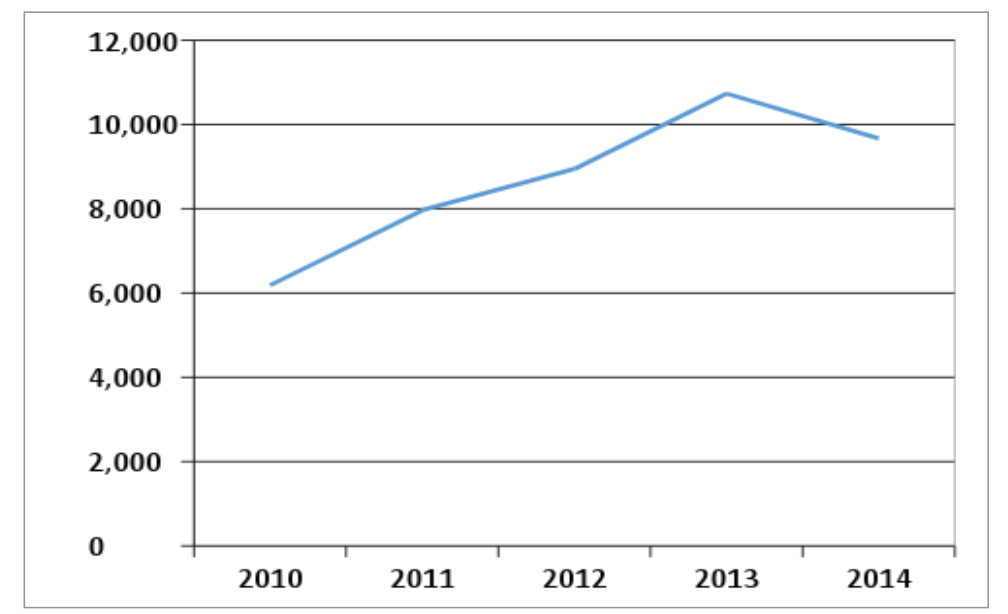

Sumber: Data Keuangan BPD Seluruh Indonesia (ASBANDA) 2014

Gambar 1. Pertumbuhan Laba BPD Tahun 2010 sd 2014 (dalam milyar rupiah) 
Ketentuan tentang investasi pemerintah diatur dalam UU No. 1 Tahun 2004 tentang Perbendaharaan Negara, Pasal 41, ayat (1) Pemerintah dapat melakukan investasi jangka panjang untuk memperoleh manfaat ekonomi, sosial dan/atau manfaat lainnya. Ayat (2) Investasi sebagaimana dimaksud pada ayat (1) dilakukan dalam bentuk saham, surat utang, dan investasi langsung. Ayat (3) Investasi sebagaimana dimaksud pada ayat (1) diatur dengan peraturan pemerintah. Ayat (4) Penyertaan modal pemerintah pusat pada perusahaan negara/ daerah/swasta ditetapkan dengan peraturan pemerintah. Penyertaan modal pemerintah daerah pada perusahaan negara/ daerah/swasta ditetapkan dengan peraturan daerah.

Sektor perbankan merupakan salah satu sektor usaha yang strategis dan penting dalam menunjang perekonomian suatu negara. Perbankan yang berperan sebagai lembaga perantara keuangan, berperan sangat penting dalam sistem perekonomian suatu negara. Perbankan adalah segala sesuatu yang berkaitan dengan bank, mencakup kelembagaan, kegiatan usaha, serta cara dan proses dalam melaksanakan kegiatan usahanya. Perbankan Indonesia dalam menjalankan fungsinya berasaskan demokrasi ekonomi dan menggunakan prinsip kehatihatian. Fungsi utama Perbankan Indonesia adalah sebagai penghimpun dan penyalur dana masyarakat serta bertujuan untuk menunjang pelaksanaan pembangunan nasional dalam rangka meningkatkan pemerataan pembangunan dan hasil-hasilnya, pertumbuhan ekonomi dan stabilitas nasional kearah peningkatan taraf hidup rakyat banyak. Perbankan juga memiliki kedudukan yang strategis, yakni sebagai penunjang kelancaran sistem pembayaran, pelaksanaan kebijakan moneter dan pencapaian stabilitas sistem keuangan, sehingga diperlukan perbankan yang sehat, transparan dan dapat dipertanggungjawabkan (Booklet Perbankan Indonesia 2016).

Definisi bank menurutUU No 10 Tahun 1998 yang merupakan perubahan atas UU No 7 Tahun 1992 tentang Perbankan, bank adalah badan usaha yang menghimpun dana dari masyarakat dalam bentuk simpanan dan menyalurkannya kepada masyarakat dalam bentuk kredit dan atau bentuk-bentuk lainnya dalam rangka meningkatkan taraf hidup rakyat banyak, fungsi utama perbankan Indonesia adalah sebagai penghimpun dan penyalur dana masyarakat dan perbankan Indonesia bertujuan untuk menunjang pelaksanaan pembangunan nasional dalam rangka meningkatkan pemerataan, pertumbuhan ekonomi, dan stabilitas nasional ke arah peningkatan kesejahteraan rakyat banyak, pasal 21 ayat (1) menyatakan bahwa bentuk hukum suatu bank umum dapat berupa (1) perseroan terbatas; (2) koperasi; atau (3) perusahaan daerah. Salah satu fungsi bank sebagai penyalur dana masyarakat adalah adanya pertumbuhan kredit dari tahun 2009 s.d 2014 sebagaimana tercermin dalam grafik dibawah ini:

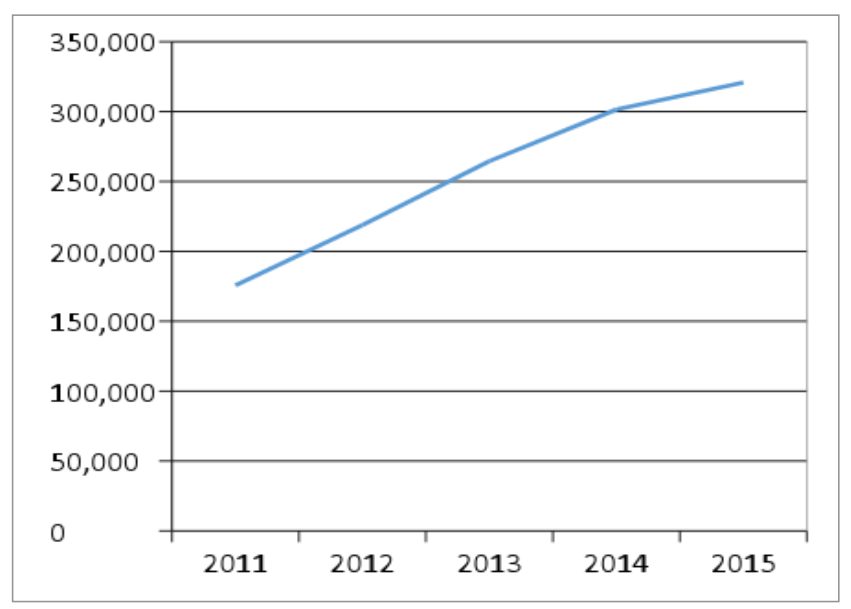

Sumber: Statistik Perbankan Indonesia terbitan OJK 2014

Gambar 2. Pertumbuhan Kredit BPD Tahun 2011 s.d. 2014 (Dalam Milyar Rupiah) 
Peraturan mengenai bank pembangunan daerah diatur dalam Keputusan Menteri Dalam Negeri Nomor 62 Tahun 1999 tentang Pedoman Organisasi dan Tata Kerja Bank Pembangunan Daerah. BPD mempunyai tugas pokok mengembangkan perekonomian dan menggerakkan pembangunan daerah melalui kegiatannya sebagai bank. BPD dalam melaksanakan tugas pokok tersebut mempunyai fungsi (1) pendorong terciptanya tingkat pertumbuhan perekonomian dan pembangunan daerah dalam rangka meningkatkan taraf hidup rakyat, (2) pemegang kas daerah dan atau menyimpan uang daerah dan (3) salah satu sumber pendapatan asli daerah.

Kredit adalah penyediaan uang atau tagihan yang dapat dipersamakan dengan itu, berdasarkan persetujuan atau kesepakatan pinjam-meminjam antara bank dengan pihak lain yang mewajibkan pihak peminjam untuk melunasi utangnya setelah jangka waktu tertentu dengan pemberian bunga (UU No. 10 Tahun 1998). Ciri dan penggunaan kredit, menurut Dinda Ayu Meitasari (2014), kredit dapat dibedakan sebagai berikut:

1. Kredit Modal Kerja (KMK) adalah fasilitas kredit yang dipergunakan untuk membiayai aktiva lancar dan atau menggantikan hutang dagang, serta membiayai sementara kegiatan operasional rutin (sehari-hari) perusahaan baik yang bersifat langsung maupun tidak langsung. Fasilitas KMK dipergunakan untuk berbagai tujuan misalnya dalam bentuk KMK ekspor, KMK impor maupun KMK lokal.

2. Kredit Transaksi Khusus adalah fasilitas kredit yang hanya sekali pakai yang ditujui untuk suatu tujuan atau beberapa tujuan tertentu.

3. Kredit Tidak Langsung (Kontijen) adalah kredit yang tidak memerlukan disposisi dana secara langsung pada saat kredit tersebut disetujui.

4. Kredit Investasi adalah fasilitas kredit yang diberikan untuk membantu pembiayan pemohon dalam memperoleh barang modal selain tanah yang tercermin dalam aktiva tetap perusahaan, dalam memberikan kredit investasi tersebut harus diperhatikan kemampuan keuangan untuk mengangsur pokok kredit setiap periode tertentu, sehingga risiko bank makin berkurang.

5. Kredit Konsumtif adalah kredit yang diberikan untuk membiayai kebutuhan konsumtif yang diperlukan pemohon dan sumber pembayaran kembali kreditnya berasal dari penghasilan/gaji pemohon.

Perbandingan antara penyaluran kredit produktif dan konsumtif pada BPD tahun 2011 s.d 2015 tergambar dalam grafik dibawah ini:

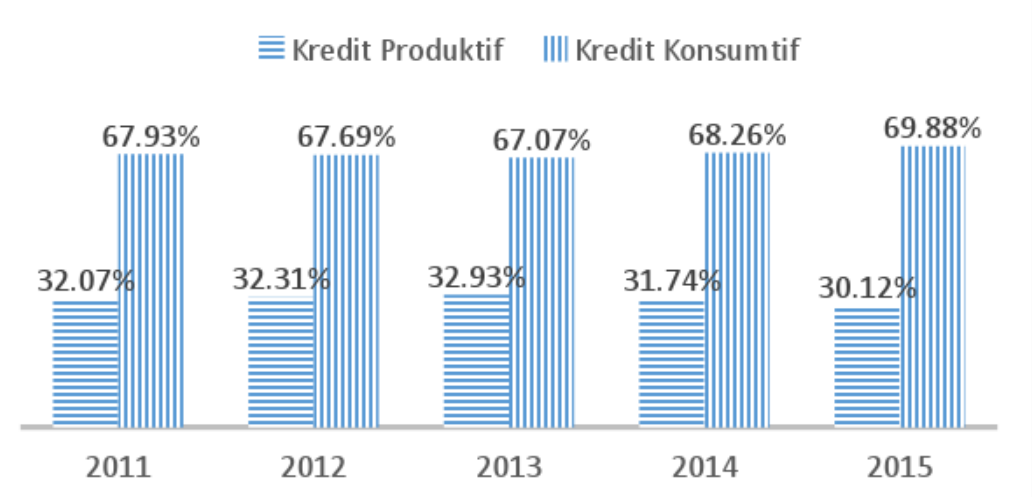

Sumber: Statistik Perbankan Indonesia terbitan OJK 2015

Gambar 3. Perbandingan Kredit Produktif dengan Kredit Konsumtif BPD

Tahun 2011 sd 2015

(dalam Milyar rupiah) 
Investasi adalah aset yang digunakan untuk memperoleh manfaat ekonomi seperti bunga, dividen, dan royalti atau manfaat sosial sehingga dapat meningkatkan kemampuan pemerintah dalam rangka pelayanan kepada masyarakat (PP 71 Tahun 2010). Berbeda dengan investasi yang dilakukan oleh pihak swasta, investasi yang dilakukan oleh pemerintah daerah dilakukan melalui mekanisme pengeluaran pembiayaan dalam Anggaran Pendapatan dan Belanja Daerah (APBD). Peraturan mengenai investasi pemerintah daerah diatur melalui Peraturan Menteri Dalam Negeri Republik Indonesia Nomor 52 Tahun 2012 tentang Pedoman Pengelolaan Investasi Pemerintah Daerah, investasi pemerintah daerah dimaksudkan untuk memperoleh manfaat ekonomi, sosial, dan/atau manfaat lainnya. Investasi pemerintah daerah bertujuan untuk: (1) meningkatkan pertumbuhan dan perkembangan perekonomian daerah; (2) meningkatkan pendapatan daerah; dan (3) meningkatkan kesejahteraan masyarakat.

Peraturan Bank Indonesia Nomor 13/1/ PBI/2011 tentang Penilaian Tingkat Kesehatan Bank Umum dijelaskan bahwa: (1) bank wajib memelihara dan/atau meningkatkan tingkat kesehatan bank dengan menerapkan prinsip kehati-hatian dan manajemen risiko dalam melaksanakan kegiatan usaha. (2) dalam rangka melaksanakan tanggung jawab atas kelangsungan usaha bank, direksi dan dewan komisaris bertanggung jawab untuk memelihara dan memantau tingkat kesehatan bank serta mengambil langkah-langkah yang diperlukan untuk memelihara dan/atau meningkatkan tingkat kesehatan bank sebagaimana dimaksud pada ayat (1), bank wajib melakukan penilaian tingkat kesehatan dengan menggunakan pendekatan risiko (Risk-based Bank Rating) baik secara individual maupun secara konsolidasi.

Sejalan dengan penelitian yang dilakukan olehDian,FaridadanDikky(2011)menyimpulkan bahwa pemerintah dapat melakukan investasi jangka pendek yakni investasi pada produk perbankan di bank yang sehat yakni deposito dan tabungan (simpanan). Investasi jangka panjang dapat dilakukan oleh pemerintah pada produk perbankan pada seluruh bank yang sehat, seperti deposito, tabungan (simpanan), dan obligasi pemerintah. Penelitian yang dilakukan oleh Natanegara (2004) menyatakan bahwa penyertaan modal pemerintah daerah juga berpengaruh positif terhadap kinerja (ROE) PT Bank Pembangunan Daerah Sumatera Selatan, semakin besar penyertaan modal Pemda yang disetor semakin tinggi pula kinerja (ROE) PT Bank Pembangunan Daerah Sumatera Selatan.

Kinerja perbankan dapat dinilai dengan pendekatan analisis rasio keuangan, umumnya digunakan lima aspek penilaian yaitu: CAMEL (Capital, Asset Quality, Management, Earning dan Liquidity), rasio keuangan perbankan dalam penelitian ini adalah (1) Capital Adequacy Ratio (CAR) untuk aspek permodalan, (2) Non Performing Loan (NPL) untuk aspek kualitas aset, (3) Net Profit Margin (NPM) untuk aspek manajemen, (4) Return on Asset (ROA) dan Beban Operasional pada Pendapatan Operasional (BOPO) untuk aspek rentabilitas, serta (5) Loan to Deposit Ratio (LDR) untuk aspek likuiditas (Supatmi dan Kristanto 2012).

Pemerintah daerah yang melakukan investasi terhadap bank pembangunan daerah sangat berkepentingan terhadap kinerja dan kesehatan bank pembangunan daerah tersebut. Kepentingan tersebut diantaranya bank pembangunan daerah dapat menjadi agen pertumbuhan ekonomi, kas daerah disimpan di bank pembangunan daerah sehingga secara langsung maupun tidak langsung likuiditasnya akan mempengaruhi manajemen kas daerah dan bank pembangunan daerah diharapkan dapat memberikan kontribusi pendapatan asli daerah dari laba yang diperolehnya.

\section{Telaah Teori dan Pengembangan Hipotesis}

Keuangan publik adalah bagian dari ilmu ekonomi yang mempelajari aktivitas finansial pemerintah dan bagaimana proses 
pengambilan keputusan yang dilakukan oleh pemerintah. Setiap keputusan yang diambil akan mempunyai pengaruh terhadap ekonomi, keuangan rumah tangga, dan swasta. Oleh karena itu, masyarakat sebagai para pemilih wakil rakyat yang membuat keputusan, perlu memonitor aktivitas para wakilnya apakah telah membuat kebijakan yang memihak pada rakyat. Keuangan publik, mempelajari pendapatan dan belanja pemerintah, juga menganalisis implikasi dari kegiatan pendapatan dan belanja pada alokasi sumber daya, distribusi pendapatan, dan stabilitas ekonomi (BPPK 2010).

Penganggaran atau proses penyusunan anggaran publik memiliki karakteristik yang berbeda dengan penganggaran dalam bisnis. Menurut Nurul Latifah P (2010) karakteristik tersebut mencakup (1) ketersediaan sumberdaya, (2) motiflaba, (3) barang publik, (4) eksternalitas, (5) penentuan harga pelayanan publik, dan (6) perbedaan lain seperti intervensi pemerintah terhadap perekonomian melalui anggaran, kepemilikan atas organisasi, dan tingkat kesulitan dalam proses pembuatan keputusan.

Nurul Latifah P (2010) juga menjelaskan bahwa anggaran merupakan alat utama pemerintah untuk melaksanakan semua kewajiban, janji, dan kebijakannya ke dalam rencana-rencana konkrit dan terintegrasi dalam hal tindakan apa yang akan diambil, hasil apa yang akan dicapai, pada biaya berapa dan siapa yang akan membayar biaya-biaya tersebut dan anggaran yang ditetapkan dapat dipandang sebagai suatu kontrak kinerja antara legislatif dan eksekutif. Penganggaran publik adalah pencerminan dari kekuatan relatif dari berbagai budget actors yang memiliki kepentingan atau preferensi berbeda terhadap outcomes anggaran. Adanya keterbatasan dana yang dimiliki oleh pemerintah menjadi alasan mengapa penganggaran menjadi mekanisme terpenting untuk pengalokasian sumberdaya dan penganggaran di sektor publik merupakan suatu bargaining process antara eksekutif dan legislatif.
Karakteristik penganggaran sektor publik menurut Indra Bastian (2006) adalah sebagai berikut:

1. Anggaran dinyatakan dalam satuan keuangan dan satuan non keuangan;

2. Anggaran umumnya mencakup jangka waktu tertentu, satu atau beberapa tahun;

3. Anggaran berisi komitmen atau kesanggupan manajemen untuk mencapai sasaran yang ditetapkan;

4. Usulan anggaran ditelaah dan disetujui oleh pihak yang berwenang lebih tinggi dari pihak penyusun anggaran; dan

5. Sekali disusun, anggaran hanya dapat diubah dalam kondisi tertentu.

Teori keagenan yang menjelaskan hubungan prinsipal dan agen berakar pada teori ekonomi, teori keputusan, sosiologi, dan teori organisasi (Jhon Andra Asmara 2010). Teori keagenan menganalisis susunan kontraktual di antara dua atau lebih individu, kelompok, atau organisasi. Salah satu pihak (principal) membuat suatu kontrak, baik secara implisit maupun eksplisit, dengan pihak lain (agent) dengan harapan bahwa agen akan bertindak/melakukan pekerjaan seperti yang dinginkan oleh prinsipal (dalam hal ini terjadi pendelegasian wewenang).

Perbankan adalah segala sesuatu yang berkaitan dengan bank, mencakup kelembagaan, kegiatan usaha, serta cara dan proses dalam melaksanakan kegiatan usahanya. Perbankan Indonesia dalam menjalankan fungsinya berasaskan demokrasi ekonomi dan menggunakan prinsip kehati-hatian. Fungsi utama perbankan Indonesia adalah sebagai penghimpun dan penyalur dana masyarakat serta bertujuan untuk menunjang pelaksanaan pembangunan nasional dalam rangka meningkatkan pemerataan pembangunan dan hasil-hasilnya, pertumbuhan ekonomi dan stabilitas nasional, kearah peningkatan taraf hidup rakyat banyak. Perbankan memiliki kedudukan yang strategis, yakni sebagai penunjang kelancaran sistem pembayaran, pelaksanaan kebijakan moneter dan pencapaian 
stabilitas sistem keuangan, sehingga diperlukan perbankan yang sehat, transparan dan dapat dipertanggungjawabkan (Booklet Perbankan Indonesia 2016).

Thomas Suyatno dan Djuhaepah (2007) menyatakan bahwa sebagai lembaga keuangan bank memiliki usaha pokok berupa menghimpun dana yang (sementara) tidak dipergunakan untuk kemudian menyalurkan kembali dana tersebut kedalam masyarakat untuk jangka waktu tertentu. Fungsi untuk mencari dan selanjutnya menghimpun dana dalam bentuk simpanan (deposit) sangat menentukan pertumbuhan suatu bank, sebab volume dana yang berhasil dihimpun atau disimpan tentunya akan menentukan volume yang dapat dikembangkan oleh bank tersebut dalam bentuk penanaman dana yang menghasilkan, misalnya dalam bentuk pemberian kredit, pembelian efek-efek atau surat berharga dalam pasar uang.

Dasar hukum pendirian Bank Pembangunan Daerah adalah UU Nomor 13 Tahun 1962 tentang Ketentuan - Ketentuan Pokok Bank Pembangunan Daerah. Menurut UU Nomor 13 Tahun 1962 tersebut, pendirian Bank Pembangunan Daerah dimaksudkan untuk menyediakan pembiayaan bagi pelaksanaan usaha - usaha pembangunan daerah dalam rangka pembangunan nasional semesta. Bank Pembangunan daerah lebih mengutamakan pemberian kredit jangka menengah dan panjang di bidang pembangunan. Bank Pembangunan Daerah juga berperan sebagai pemegang kas Pemerintah Daerah.

Novy GA Palenkahu (2014) menyatakan bahwa karakateristik BPD berbeda dengan bank umum lainnya, sebagaimana diatur dalam UU No. 13 tahun 1962 bahwa "Daerah usaha BPD terbatas pada wilayah dimana BPD tersebut didirikan, kecuali apabila ternyata ada suatu daerah yang tidak/belum dapat mendirikannya, maka daerah tersebut dapat menggunakan jasajasa BPD dari daerah lain yang berbatasan.”

Perkembangan BPD saat ini menunjukkan ada beberapa BPD yang pengembangan usahanya telah jauh melewati batas wilayah dimana BPD tersebut didirikan seperti PT Bank DKI dan PT Bank Jabar Banten. PT Bank DKI saat ini selain di DKI Jakarta mempunyai cabang di sembilan provinsi lain sedangkan PT Bank Jabar Banten selain di Jawa Barat dan Banten mempunyai cabang di 12 provinsi lain.

Kredit berasal dari bahasa Italia, credare yang berarti kepercayaan, yaitu kepercayaan dari kreditor (pemberi pinjaman) bahwa debitornya (penerima pinjaman) akan mengembalikan pinjaman beserta bungannya sesuai dengan perjanjian kedua belah pihak. Unsur kredit yang paling esensial adalah "kepercayaan" dari bank/ kreditur terhadap nasabah/debitur. Kepercayaan tersebut timbul karena dipenuhinya segala ketentuan dan persyaratan untuk memperoleh kredit bank oleh debitur, antara lain, jelasnya tujuan peruntukan kredit, adanya benda jaminan atau agunan, dan lain-lain (Iswi Hariyani, 2010).

Menurut UU Nomor 10 Tahun 1998 tentang Perubahan Atas UU Nomor 7 Tahun 1992 tentang Perbankan, pasal 1 angka 11, kredit adalah penyediaan uang atau tagihan yang dapat dipersamakan dengan itu, berdasarkan persetujuan atau kesepakatan pinjam-meminjam antara bank dengan pihak lain yang mewajibkan pihak peminjam untuk melunasi utangnya setelah jangka waktu tertentu dengan pemberian bunga.

Fungsi kredit bagi masyarakat antara lain sebagai motivator dan dinamisator dalam peningkatan kegiatan perdagangan dan perekonomian, menambah lapangan kerja bagi masyarakat dan memperlancar arus barang dan arus uang. Tujuan kredit antara lain yaitu memperoleh pendapatan bank dari hasil bunga kredit yang diterima, memproduktifkan dan memanfaatkan dana-dana yang ada, melaksanakan kegiatan operasional bank dan untuk memenuhi permintaan kredit dari masyarakat.

Naufal Ferdyan Asrori (2010) mengatakan bahwa jenis kredit berdasarkan tujuan/ kegunaannya dibedakan menjadi: 
1. Kredit konsumtif, yaitu adalah kredit yang digunakan dalam rangka pengadaan barang atau jasa untuk tujuan konsumsi, dan bukan sebagai barang modal dalam kegiatan usaha nasabah. Kredit ini tidak termasuk kredit produktif.

2. Kredit modal kerja (kredit perdagangan) ialah kredit yang akan dipergunakan untuk menambah modal usaha atau membiayai modal kerja debitur. KMK biasanya berjangka pendek dan disusuaikan dengan jangka waktu perputaran modal kerja nasabah. Kredit jenis ini termasuk jenis kredit produktif.

3. Kredit investasi ialah kredit yang dipergunakan untuk investasi produktif, tetapi baru akan menghasilkan dalam jangka waktu yang relatif lama, biasanya kredit ini diberikan grace period, misalnya kredit untuk perkebunan kelapa sawit, dan lain-lain.

Kredit produktif didefinisikan sebagai kredit yang diberikan kepada usaha-usaha yan menghasilkan barang dan jasa sebagai kontribusi daripada usahanya. Kredit ini terdiri dari:

1. Kredit Modal Kerja, yaitu kredit yang diberikan untuk membiayai kebutuhan usaha-usaha, termasuk guna menutupi biaya produksi dalam rangka peningkatan produksi atas penjualan; dan

2. Kredit Investasi, yaitu kredit yang diberikan untuk pengadaan barang modal maupun jasa yang dimaksudkan untuk menghasilkan suatu barang dan ataupun jasa bagi usaha yang bersangkutan.

Sebaliknya kredit konsumsi adalah kredit yang diberikan kepada orang-perorangan untuk memenuhi kebutuhan konsumsi masyarakat umumnya (YLBHI dan PSHK, 2007).

UU No 13 Tahun 1962 menyebutkan bahwa BPD didirikan dengan maksud khusus untuk menyediakan pembiayaan bagi pelaksanaan usaha-usaha pembangunan daerah dalam rangka Pembangunan Nasional Semesta Berencana. BPD hanya diperbolehkan memberikan pinjaman/kredit untuk keperluan investasi, perluasan dan pembaruan proyek-proyek pembangunan daerah. BPD tidak memberikan pembiayaan di luar bidang tersebut.

Investasi adalah aset yang dimaksudkan untuk memperoleh manfaat ekonomi seperti bunga, dividen, dan royalti atau manfaat sosial sehingga dapat meningkatkan kemampuan pemerintah dalam rangka pelayanan kepada masyarakat (PP No. 71 Tahun 2010). Investasi yang dilakukan oleh pemerintah terdiri dari dua jenis yaitu investasi permanen dan investasi non permanen. Investasi permanen terdiri dari Penyertaan Modal Pemerintah pada perusahaan negara/perusahaan daerah, lembaga keuangan negara, badan hukum milik negara, badan internasional dan badan hukum lainnya bukan milik negara; dan investasi permanen lainnya.

Investasi Pemerintah adalah penempatan sejumlah dana dan/atau barang dalam jangka panjang untuk investasi pembelian surat berharga dan investasi langsung untuk memperoleh manfaat ekonomi, sosial, dan/atau manfaat lainnya. Pemerintah dapat melakukan investasi dengan cara investasi langsung. Investasi berupa penyertaan modal atau pemberian pinjaman dengan cara public private partnership kerjasama Badan Investasi Pemerintah dengan Pemda, BLU, BLUD, Badan Usaha dan Badan Usaha Asing (Zainul Fuad, 2014).

Deddy Supriady Bratakusumah dan Dadang Solihin (2004) menyatakan pemerintah daerah dapat melakukan investasi dalam bentuk penyertaan modal, deposito atau bentuk investasi lainnya sepanjang hal tersebut memberi manfaat bagi peningkatan pelayanan masyarakat dan tidak mengganggu likuiditas pemerintah daerah, yang dimaksud dengan investasi dalam bentuk penyertaan modal adalah penyertaan modal pemerintah daerah yang dilakukan melalui Badan Usaha Milik Daerah dan yang dimaksud dengan deposito adalah simpanan berjangka yang disimpan pada bank yang sehat. Sumber-sumber pembiayaan lain dan investasi pemerintah daerah diatur 
dengan suatu Peraturan Daerah dan Pemerintah Daerah tersebut harus bertanggung jawab atas pengelolaan sumber-sumber pembiayaan lain dan investasi serta setiap akhir tahun anggaran selesai harus melaporkan hasil pelaksanaannya kepada DPRD.

Berbeda dengan investasi yang dilakukan oleh pihak swasta, investasi yang dilakukan oleh pemerintah daerah dilakukan melalui mekanisme pengeluaran pembiayaan dalam Anggaran Pendapatan dan Belanja Daerah (APBD). Peraturan Menteri Dalam Negeri Republik Indonesia Nomor 52 Tahun 2012 tentang Pedoman Pengelolaan Investasi Pemerintah Daerah, investasi pemerintah daerah dimaksudkan untuk memperoleh manfaat ekonomi, sosial, dan/atau manfaat lainnya. Investasi pemerintah daerah bertujuan untuk: (1) meningkatkan pertumbuhan dan perkembangan perekonomian daerah; (2) meningkatkan pendapatan daerah; dan (3) meningkatkan kesejahteraan masyarakat.

CAR adalah rasio yang memperhitungkan seberapa jauh seluruh aktiva bank yang mengandung risiko (kredit, penyertaan, surat berharga, tagihan pada bank lain), ikut dibiayai dari dana modal sendiri bank. Dengan kata lain CAR adalah rasio kinerja bank untuk mengukur kecukupan modal yang dimiliki bank untuk menunjang aktiva yang mengandung atau menghasilkan risiko, misalnya kredit yang diberikan (Farah Margaretha, 2007).

Penyediaan modal minimum diatur dalam Peraturan Bank Indonesia Nomor 15/12/ PBI/2013 tentang Kewajiban Penyediaan Modal Minimum Bank Umum, pasal 2 ayat (1) bank wajib menyediakan modal minimum sesuai profil risiko. Ayat (2) modal minimum sebagaimana dimaksud pada ayat (1) ditetapkan paling rendah sebagai berikut:

1. $8 \%$ (delapan persen) dari Aset Tertimbang Menurut Risiko (ATMR) untuk Bank dengan profil risiko peringkat 1 (satu);

2. $9 \%$ (sembilan persen) sampai dengan kurang dari 10\% (sepuluh persen) dari
ATMR untuk Bank dengan profil risiko peringkat 2 (dua);

3. $10 \%$ (sepuluh persen) sampai dengan kurang dari 11\% (sebelas persen) dari ATMR untuk Bank dengan profil risiko peringkat 3 (tiga); atau

4. $11 \%$ (sebelas persen) sampai dengan $14 \%$ (empat belas persen) dari ATMR untuk Bank dengan profil risiko peringkat 4 (empat) atau peringkat 5 (lima).

NPL merupakan rasio keuangan yang digunakan untuk melihat tingkat pengembalian kredit yang diberikan deposan kepada bank dengan kata lain NPL merupakan tingkat kredit macet pada bank tersebut, semakin rendah NPL maka bank tersebut akan semakin mengalami keuntungan, sebaliknya bila tingkat NPL tinggi bank tersebut akan mengalami kerugian yang diakibatkan tingkat pengembalian kredit macet.

Kredit bermasalah adalah kredit yang kategori kolektibilitasnya diluar kolektibilitas lancar dan kredit dalam perhatian khusus. Kredit bermasalah mencakup kredit kurang lancar, diragukan dan macet (Boy Leon dan Sonny Ericson, 2007). Implikasi bagi bank sebagai akibat dari timbulnya kredit bermasalah tersebut adalah hilangnya kesempatan untuk memperoleh pendapatan dari kredit yang diberikan sehingga mengurangi perolehan laba dan mempengaruhi rentabilitas bank, rasio kualitas aktiva produktif menjadi semakin besar sehingga memperburuk kinerja bank dan bank harus memperbesar cadangan untuk penyisihan penghapusan aktiva produktif yang diklasifikasikan sesuai ketentuan yang ditetapkan Bank Indonesia, yang akhirnya akan mengurangi besarnya modal bank dan akan sangat bepengaruh terhadap CAR.

Rasio BOPO adalah rasio yang digunakan untuk mengukur tingkat efisiensi dan kemampuan bank dalam melakukan kegiatan operasinya (Boy Leon dan Sonny Ericson, 2007). Perusahaan yang bergerak dibidang perbankan, melakukan efisiensi operasi, yaitu untuk mengetahui apakah bank dalam operasinya yang berhubungan dengan usaha 
pokok bank, dilakukan dengan benar dalam arti sesuai yang diharapkan manajemen dan pemegang saham (Zulfikar). Efisiensi operasi juga mempengaruhi kinerja bank, yakni untuk menunjukkan apakah bank telah mengunakan seluruh faktor produksinya dengan tepat guna dan berhasil guna. Rasio efisiensi bank juga bisa diukur dengan total non interest expense divided by total interest income minus total interest expense plus total non interest income (Zulfikar). Menurut ketentuan Bank Indonesia efisiensi operasi diukur dengan mengunakan rasio biaya operasional dibandingkan dengan pendapatan operasional. Mengingat kegiatan utama bank adalah bertindak sebagai perantara, yaitu menghimpun dana dan menyalurkan dana masyarakat, maka biaya dan pendapatan operasional bank didominasi oleh biaya bunga dan hasil bunga.

Laporan keuangan menurut PSAK No. 1 adalah suatu penyajian terstruktur dari posisi keuangan dan kinerja keuangan suatu entitas. Tujuan laporan keuangan adalah memberikan informasi mengenai posisi keuangan, kinerja keuangan, dan arus kas entitas yang bermanfaat bagi sebagian besar kalangan pengguna laporan dalam pembuatan keputusan ekonomi. Laporan keuangan juga menunjukkan hasil pertanggungjawaban manajemen atas penggunaan sumber daya yang dipercayakan kepada mereka. Laporan keuangan menyajikan informasi mengenai entitas yang meliputi asset, liabilitas, ekuitas, pendapatan dan beban termasuk keuntungan dan kerugian, kontribusi dari dan distribusi kepada pemilik dalam kapasitasnya sebagai pemili dan arus kas.

Informasi tersebut, beserta informasi lainnya yang terdapat dalam catatan atas laporan keuangan, membantu pengguna laporan dalam memprediksi arus kas masa depan dan khususnya dalam hal waktu dan kepastian diperolehnya kas dan setara kas. Berdasarkan teori dan bukti empiris sebelumnya, hipotesis penelitian dirumuskan sebagai berikut.

Hipotesis 1: Penyertaan modal berpengaruh terhadap Kredit Produktif.

Hipotesis 2: CAR berpengaruh terhadap Kredit Produktif.

Hipotesis 3: NPL berpengaruh terhadap Kredit Produktif.

Hipotesis 4: BOPO berpengaruh terhadap Kredit Produktif.

\section{Metode}

Penelitian ini menggunakan data sekunder. Data diperoleh dari publikasi laporan keuangan bank pembangunan daerah pada Bank Indonesia (BI) dan Otoritas Jasa Keuangan (OJK). Penelitian ini bertujuan menguji hipotesis yang telah dirumuskan pada awal penelitian. Data dalam penelitian ini adalah Laporan Keuangan Bank Pembangunan Daerah yang telah dipublikasikan oleh Bank Indonesia (BI) dan Otoritas Jasa Keuangan (OJK), dengan kurun waktu tahun 2010 s.d 2015.

Populasi dalam penelitian ini adalah seluruh laporan keuangan bank pembangunan daerah seluruh Indonesia yang dipublikasikasikan melalui BI dan OJK. Teknik pengambilan sampel yang digunakan pada penelitian ini menggunakan purposive sampling, karena teknik ini berdasarkan pada ciri-ciri atau sifatsifat tertentu yang diperkirakan mempunyai keterkaitan dengan ciri-ciri atau sifat-sifat yang ada dalam populasi yang sudah diketahui sebelumnya.

Model analisis yang digunakan adalah regresi linier berganda (multiple regression analysis model) dengan persamaan kuadrat terkecil (Ordinary Least Square) dengan model sebagai berikut:

\section{KRED PROD $=$ b1PMOD + b2CAR + b3NPL + b4BOPO}

dimana :

$\begin{array}{ll}\text { KRED PROD } & =\text { Kredit Produktif } \\ \mathrm{b} 1, \mathrm{~b} 2, \mathrm{~b} 3, \mathrm{~b} 4 & =\text { Koefisien Regresi } \\ \text { PMOD } & =\text { Penyertaan Modal } \\ \text { CAR } & =\text { CAR } \\ \text { NPL } & =\text { NPL } \\ \text { BOPO } & =\text { BOPO }\end{array}$




\section{Hasil Penelitian dan Pembahasan}

Berdasarkan hasil pengujian normalitas dan asumsi klasik, maka data memenuhi unsurunsur tersebut. Seluruh data berdistribusi normal dan terbebas dari persoalan autokorelasi, multikolonieritas, dan heteroskedastisitas. Sehingga analisis dapat dilanjutkan kejenjang berikutnya, yaitu analisis regresi dan pengujian goodness of fit.

Analisis regresi dilakukan dengan menempatkan Kredit Produktif sebagai variabel dependen, dan Penyertaan Modal, CAR, NPL dan BOPO sebagai variabel independen. Hasil analisis regresi dapat dilihat pada Tabel 1 berikut ini.

Tabel 1. Hasil Pengujian Regresi

\begin{tabular}{lrrl}
\hline Keterangan & \multicolumn{1}{c}{ B } & t-hitung & Sig. \\
\hline Penyertaan Modal &, 160 & 3,373 & 0,001 \\
CAR &, 148 & 1,329 & 0,189 \\
NPL) &, 228 & 1,921 & 0,059 \\
BOPO) &, 189 & 3,356 & 0,001 \\
Constant &, 00 & & \\
R-Square &, 319 & & \\
Adjusted R-Square &, 276 & & \\
F-hitung & 7,393 & & \\
Sig. F &, 000 & & \\
\hline
\end{tabular}

Berdasarkan Tabel 1 tersebut di atas, maka dapat diketahui bahwa persamaan regresi yang terbentuk adalah: dalam kondisi konstan. Koefisien regresi BOPO sebesar 0,189, berarti jika BOPO mengalami peningkatan sebesar 1 maka Kredit Produktif akan peningkatan sebesar 0,189 dengan asumsi variabel lain dalam kondisi konstan.

Koefisien determinasi digunakan untuk mengukur seberapa jauh kemampuan model dalam menerangkan variasi variabel independen. Hasil pengujian koefisien determinasi didapat nilai $R$ adalah 0,565 , $R$ Square sebesar 0,319 dan Adjusted R Square sebesar 0,276. Nilai F hitung adalah 7,393 jika dibandingkan dengan nilai $F$ tabel sebesar 2,52 didapat nilai $F$ hitung lebih besar dari $\mathrm{F}$ tabel maka disimpulkan bahwa terdapat pengaruh Penyertaan Modal, CAR dan BOPO secara simultan terhadap Kredit Produktif.

\section{Pengujian Hipotesis}

Pengujian hipotesis dilakukan dengan membandingkan bilai $t_{\text {tabel }}$ dan $t_{\text {hitung }}$ atau dengan melihat nilai signifikansi t (sig-t).

Hipotesis 1: Variabel penyertaan modal memiliki $\mathrm{t}$ hitung sebesar 3,373 dan tingkat signifikansi sebesar 0,001 . Nilai $t$ hitung tersebut lebih besar dari nilai $\mathrm{t}$ tabel sebesar 1,998 dan nilai signifikansi tersebut lebih kecil dari nilai yang ditetapkan yaitu 0,05 . Sehingga dapat disimpulkan bahwa penyertaan modal berpengaruh terhadap kredit produktif. Hasil penelitian ini sejalan dengan penelitian yang

\section{Kredit Produktif $=\quad 0,160 P M O D+0,148 C A R+0,228 \mathrm{NPL}+0,189 \mathrm{BOPO}$}

Dari persamaan tersebut dapat diartikan koefisien regresi PMOD sebesar 0,160, berarti jika PMOD mengalami peningkatan sebesar 1 maka Kredit Produktif akan meningkat sebesar 0,160 dengan asumsi variabel lain dalam kondisi konstan. Koefisien regresi CAR sebesar 0,148, berarti jika CAR mengalami peningkatan sebesar 1 maka Kredit Produktif akan meningkat sebesar 0,148 dengan asumsi variabel lain dalam kondisi konstan. Koefisien regresi NPL sebesar 0,228 , berarti jika NPL mengalami peningkatan sebesar 1 maka Kredit Produktif akan meningkat sebesar 0,228 dengan asumsi variabel lain dilakukan oleh Novy GA Palenkahu (2014), tetapi tidak mendukung penelitian yang dilakukan oleh Sudarno, M. Syafi'i Idrus, Ubud Salim dan Djumahir (2011) dan Izak Kelbulan dan Ch. Heni Kurniawan (2013).

Hipotesis 2: Variabel CAR memiliki $\mathrm{t}$ hitung sebesar 1,329 dan tingkat signifikansi sebesar 0,189. Nilai t hitung tersebut lebih kecil dari nilai $\mathrm{t}$ tabel sebesar 1,997 dan nilai signifikansi tersebut lebih besar dari nilai yang ditetapkan yaitu 0,05 . Sehingga dapat disimpulkan bahwa CAR tidak berpengaruh terhadap kredit produktif. Hasil penelitian 
ini mendukung penelitian Bagust Budiman Supiatno, R. Adri Satriawan S dan Desmiawati (2011) dan Dwi Fajar Febrianto dan Dul Muid (2013), tetapi tidak mendukung hasil penelitian Amalia Yuliana (2014), Amalia Yuliana (2014) dan Naufal Ferdyan Asrori (2010).

Hipotesis 3: Variabel NPL memiliki thitung sebesar 1,921 dan tingkat signifikansi sebesar 0,059 . Nilai t hitung tersebut lebih kecil dari nilai $\mathrm{t}$ tabel sebesar 1,997 dan nilai signifikansi tersebut lebih besar dari nilai yang ditetapkan yaitu 0,05. Sehingga dapat disimpulkan bahwa NPL tidak berpengaruh terhadap kredit produktif. Hasil penelitian ini mendukung penelitian Bagust Budiman Supiatno, R. Adri Satriawan S., Desmiawati, (2011), Amalia Yuliana (2014), Zulcha Mintachus Sania dan Dewi Urip Wahyuni (2016).

Hipotesis 4: Variabel BOPO memiliki $\mathrm{t}$ hitung sebesar 3,356 dan tingkat signifikansi sebesar 0,001 . Nilai $t$ hitung tersebut lebih besar dari nilai $t$ tabel sebesar 1,998 dan nilai signifikansi tersebut lebih kecil dari nilai yang ditetapkan yaitu 0,05 . Sehingga dapat disimpulkan bahwa BOPO berpengaruh terhadap kredit produktif. Hasil penelitian ini mendukung penelitian Dwinur Arianti, Rita Andini dan Rina Arifati (2016) tetapi tidak mendukung hasil penelitian Cut Putri Malahayati dan Kartika Sukmawati (2015) dan Dwi Fajar Febrianto dan Dul Muid (2013).

\section{Simpulan, Keterbatasan, dan Implikasi Hasil Penelitian}

Berdasarkan hasil analisis data dan pembahasan tersebut di atas, maka dapat diambil beberapa kesimpulan yaitu, pengujian hipotesis pertama menunjukkan bahwa terdapat pengaruh positif dan signifikan antara penyertaan modal terhadap kredit produktif, hasil pengujian ini mendukung hipotesis yang diajukan, hal ini juga menunjukkan bahwa semakin besar penyertaan modal yang dilakukan oleh pemerintah daerah terbukti meningkatkan penyaluran kredit produktif oleh BPD. Pengujian hipotesis kedua menunjukkan tidak terdapat pengaruh antara
CAR terhadap kredit produktif, dengan demikian hasil penelitian ini tidak mendukung hipotesis kedua. Pengujian hipotesis ketiga menunjukkan bahwa tidak terdapat pengaruh antara NPL terhadap kredit produktif, hasil pengujian ini tidak mendukung hipotesis yang diajukan dengan meningkatnya NPL tidak berpengaruh terhadap kredit produktif. Pengujian hipotesis keempat menunjukkan terdapat pengaruh antara BOPO terhadap kredit produktif, dengan demikian hasil penelitian ini mendukung hipotesis keempat.

Penelitian ini mempunyai keterbatasan baik dalam pengambilan sampel maupun dalam pengukuran variabel. Beberapa keterbatasan dalam penelitian ini antara lain, jumlah sampel yang diperoleh pada penelitian ini terbatas pada publikasi laporan keuangan BPD yang bersumber dari situs-situs laman BPD terkait. Penelitian ini hanya menggunakan variabel penyertaan modal, CAR, NPL dan BOPO sehingga dimungkinkan adanya variabel lain yang mempengaruhi kredit produktif misalnya, tingkat suku bunga dan inflasi serta masih sedikitnya penelitian tentang penyertaan modal pemerintah terutama pemerintah daerah di Indonesia sehingga sulit untuk mencari referensi penelitian sebelumnya.

Berdasarkan kesimpulan dan keterbatasan penelitian yang telah dilakukan di atas, implikasi hasil penelitian adalah kepada Pemerintah Daerah yang akan menyertakan modal kepada BPD dapat menambah syarat dalam klausul Peraturan Daerahnya tentang kewajiban BPD untuk meningkatkan penyaluran kredit produktif dan kredit modal kerjanya. Kepada BPD yang menerima penyertaan modal dari pemerintah daerah secara rutin, agar meningkatkan penyaluran kredit produktif dan kredit modal kerjanya. Penelitian yang akan dilakukan pada masa yang akan datang diharapkan melaksanakan penelitian dengan menambah jumlah variabel agar diketahui variabel lain yang mempengaruhi penyaluran kredit produktif dan diharapkan melakukan penelitian pada topik penyertaan modal pemerintah agar diketahui pengaruhnya terhadap penyaluran kredit produktif. 


\section{Daftar Referensi}

Boy Leon dan Sonny Ericson. 2007. Manajemen Aktiva Pasiva Bank Nondevisa. PT Grasindo. Jakarta.

Deddy Supriady Bratakusumah dan Dadang Solihin. 2004. Otonomi Penyelenggaraan Pemerintah Daerah. PT Gramedia Pustaka Utama. Jakarta.

Farah Margaretha. 2007. Manajemen Keuangan Bagi Industri Jasa. Grasindo. Jakarta.

H. Abd. Rachim. 2015. Barometer Keuangan Negara/Daerah. Penerbit ANDI. Yogyakarta Indra Bastian. 2006. Akuntansi Sektor Publik: Suatu Pengantar. Penerbit Erlangga. Ciracas, Jakarta.

Iswi Hariyani. 2010. Restrukturisasi dan Penghapusan Kredit Macet. PT Elex Media Komputindo Kompas Gramedia. Jakarta.

Jimly Asshiddiqie. 2010. Konstitusi Ekonomi. PT Kompas Media Nusantara. Jakarta

Thomas Suyatno, Djuhaepah T. Marala, Azhar Abdullah, Johan Thomas Aponno, C. Tinon Yunianti dan H.A. Chalik. 2007. Kelembagaan Perbankan. PT Gramedia Pustaka Utama. Jakarta.

YLBHI dan PSHK. 2007. Panduan Bantuan Hukum di Indonesia: Pedoman Anda Memahami dan Menyelesaikan Masalah Hukum. Yayasan Obor Indonesia. Jakarta.

Zainul Fuad, Entatarina Simanjuntak dan Hasna Widiastuti. 2014. Stategi Pendayagunaan Badan Usaha Milik Pemerintah (BUMN dan BUMD) Dalam Pembiayaan Infrastruktur Pekerjaan Umum 2014. Jakarta.

Statistik Perbankan Indonesia. 2015. Otoritas Jasa Keuangan.

Amalia Yuliana. 2014. Pengaruh LDR, CAR, ROA dan NPL Terhadap Penyaluran Kredit Pada Bank Umum Di Indonesia Periode 2008 - 2013. Jurnal Dinamika Manajemen Vol. 2 No. 3 Juli-September 2014

Bagust Budiman Supiatno, R. Adri Satriawan S. dan Desmiawati. 2011. Pengaruh NPL, CAR dan Tingkat Suku Bunga Terhadap Penyaluran Kredit Perusahaan Perbankan
Yang Terdaftar Di Bursa Efek Indonesia Pada Tahun 2009-2011.

Cut Putri Malahayati dan Kartika Sukmawati. 2015. Pengaruh Bopo, Roa, Car, Npl, Dan Jumlah SBI Terhadap Penyaluran Kredit Perbankan (Studi Kasus Pada Bank Danamon Tbk Periode 2009-2013). PESAT Seminar Ilmiah Nasional Psikologi, Ekonomi, Sastra, Arsitektur \& Teknik Sipil Volume 6-Oktober 2015

Dian Yudo Palupi, Farida Ratna Dewi, dan R. Dikky Indrawan. 2011. Analisis Peluang Penyertaan Modal Pemerintah Daerah Kota XYZ pada PT Bank Jawa Barat dan Banten (Bank BJB). Jurnal Manajemen dan Organisasi Vol II, No. 1. April 2011.

Dinda Ayu Meitasari. 2014. Analisis Pengaruh Kredit Konsumtif dan Produktif terhadap Laba Bank berdasarkan Kelompok Bank. Jurnal Ilmiah Mahasiswa FEB Vol 2, No 2: Semester Genap 2013/2014.

Dwinur Arianti, Rita Andini dan Rina Arifati. 2016. Pengaruh BOPO, NIM, NPL dan CAR Terhadap Jumlah Penyaluran Kredit Pada Perusahaan Perbankan Yang Go Publik Di Bursa Efek Indonesia Periode Tahun 2010 -2014. Journal Of Accounting, Volume 2 No. 2 Maret 2016

Dwi Fajar Febrianto dan Dul Muid (2013). Analisis Pengaruh Dana Pihak Ketiga, LDR, NPL, CAR, ROA, DAN BOPO Terhadap Jumlah Penyaluran Kredit (Studi pada Bank Umum yang Terdaftar di Bursa Efek Indonesia Periode Tahun 2009-2012). Diponegoro Journal Of Accounting Volume 2, Nomor 4, Tahun 2013, Halaman 1-11

I Gusti Ayu Putri Wahyuni, Made Sukarsa dan Nyoman Yuliarmi.2014. Pengaruh Pengeluaran Pemerintah Dan Investasi Terhadap Pertumbuhan Ekonomi Dan Kesenjangan Pendapatan Kabupaten/Kota Di Provinsi Bali. E-Jurnal Ekonomi dan Bisnis Universitas Udayana 3.8 458-477.

Izak Kelbulan dan Ch. Heni kurniawan. Analisis Pengaruh Penyertaan Modal Pemerintah Daerah Terhadap Pertumbuhan Aktiva, Efisiensi, dan Kinerja Keuangan BUMD 
di Provinsi DIY. Program Studi Akuntansi Fakultas Ekonomi Universitas Atma Jaya Yogyakarta.

Jhon Andra Asmara, 2010, Analisis Perubahan

Alokasi Belanja dalam Anggaran

Pendapatan dan Belanja Aceh (APBA)

Provinsi Nangroe Aceh Darusalam, Jurnal

Telaah \& Riset Akuntansi (JTRA), Volume, 155-172.

Natanegara. 2004. Pengaruh Penyertaan Modal

Pemda Terhadap Kinerja BUMD: studi kasus pada Bank Pembangunan Sumatera Selatan. Jurnal Media Wahana Ekonomika Fakultas Ekonomi Universitas PGRI Palembang.

Naufal Ferdyan Asrori. 2010. Analisis FaktorFaktor yang Mempengaruhi Penyaluran Kredit Investasi (Studi Empiris pada Bank BUMN). Jurusan Akuntansi Fakultas Ekonomi dan Bisnis Universitas Brawijaya

Novy GA Pelenkahu. 2014. Kajian Atas Metodologi Pemeriksaan Badan Usaha Milik Daerah (Studi Kasus Pemeriksaan Bank Pembangunan Daerah). Available at: http://bahrullah.com/wp-content/ uploads/2016/01/Kajian-BPD-Net-23Des-15.pdf

Nurul Latifah P. 2010. Adakah Perilaku Oportunistikdalam Aplikasi Agency Theory

Di Sektor Publik? Is There Of Opportunistic Behavior On The Agency Theory Aplication In The Public Sector? Fokus Ekonomi Vol. 5 No. 2 Desember 2010 : 85 - 94.

Supatmi dan Ari Budi Kristanto. 2012. Determinan Kinerja Keuangan Bank Pembangunan Daerah di Indonesia. Proceeding Call Paper Pekan Ilmiah Dosen FEB UKSW, 14 Desember 2012.

Sudarno, M. Syafi'i Idrus, Ubud Salim dan Djumahir. 2011. Pengaruh Penyertaan Modal terhadap Petumbuhan Aktiva, Efisiensi dan Kinerja Keuangan pada BUMD (Studi pada BUMD/Perusahaan Daerah di Provinsi Riau). Jurnal Aplikasi Manajemen Volume 9 Nomor 2 Maret 2011. Taufik Zulfikar. Pengaruh CAR, LDR, NPL, BOPO dan NIM Terhadap Kinerja
Profitabilitas (ROA) Bank Perkreditan Rakyat di Indonesia. Universitas Katolik Parahyangan. Bandung.

Zulcha Mintachus Sania dan Dewi Urip Wahyuni.2016. Pengaruh DPK, NPL, dan CARTerhadap Jumlah Penyaluran Kredit Perbankan Persero. Sekolah Tinggi Ilmu Ekonomi Indonesia (STIESIA) Surabaya. Jurnal Ilmu dan Riset Manajemen, Volume 5, Nomor 1, Januari 2016.

Booklet Perbankan Indonesia. 2016. Otoritas Jasa Keuangan.

Keputusan Menteri Dalam Negeri Nomor 62 Tahun 1999 tentang Pedoman Organisasi Dan Tata Kerja Bank Pembangunan Daerah. Lembaga Pengkajian Keuangan Publik dan Akuntansi Pemerintah (LPKPAP-BPPK) Kementrian Keuangan. 2010. Keuangan Publik. Teori dan Aplikasi.

Peraturan Pemerintah No. 71 Tahun 2010 tentang Standar Akuntansi Pemerintahan.

Peraturan Menteri Dalam Negeri Republik Indonesia Nomor 52 Tahun 2012 tentang Pedoman Pengelolaan Investasi Pemerintah Daerah.

Peraturan Menteri Dalam Negeri Nomor 1 Tahun 1998 tentang Bentuk Hukum Bank Pembangunan Daerah

Peraturan Bank Indonesia No. 13/1/PBI/2011 tentang Penilaian Tingkat Kesehatan Bank Umum

Peraturan Bank Indonesia Nomor 15/12/ PBI/2013 tentang Kewajiban Penyediaan Modal Minimum Bank Umum.

Peraturan Bank Indonesia Nomor 15/3/PBI/2013 Tentang Transparansi Kondisi Keuangan Bank Perkreditan Rakyat

Undang-Undang No. 13 Tahun 1962 tentang Ketentuan - Ketentuan Pokok Bank Pembangunan Daerah.

Undang-Undang No 10 Tahun 1998 tentang Perubahan atas Undang Undang No. 7 Tahun 1992 tentang Perbankan.

Undang-Undang No. 17 Tahun 2003 tentang Keuangan Negara.

Undang-Undang No. 1 Tahun 2004 tentang Perbendaharaan Negara. 